pp. 11-23

\title{
PENGARUH VARIASI DIAMETER MAKSIMUM AGREGAT DALAM CAMPURAN TERHADAP KEKUATAN TEKAN BETON
}

\author{
Helwiyah Zain \\ Program Studi Teknik Sipil Universitas Abulyatama \\ Jl. Blang Bintang Lama Km. 8,5 Lampoh Keudee Aceh Besar \\ email: ocudma2h@gmail.com
}

\begin{abstract}
Abstrak: Agregat adalah butiran mineral alam yang berfungsi sebagai bahan pengisi dalam campuran beton, dan merupakan material terbesar yang terkandung didalam beton. Bahan agregat sangat berpengaruh terhadap sifat-sifat beton, sehingga pemilihan ukuran diameternya merupakan hal yang penting dalam pembuatan beton. Penelitian ini bertujuan untuk mengetahui pengaruh variasi diameter maksimum agregat dalam campuran terhadap kekuatan tekan beton. Pada penelitian ini digunakan 15 buah benda uji, dibagi dalam 3 kelompok masing-masing 5 buah benda uji. Setiap kelompok dibedakan diameter maksimum agregat yaitu: $31,5 \mathrm{~mm}, 16 \mathrm{~mm}$, dan $8 \mathrm{~mm}$. Benda uji yang digunakan pada penelitian ini adalah benda uji silinder dengan diameter $15 \mathrm{~cm}$ dan tinggi $30 \mathrm{~cm}$. Percobaan kuat tekan dilakukan pada umur benda uji 28 hari. Kuat tekan rata-rata beton untuk masing-masing kelompok benda uji berdasarkan variasi diameter maksimum agregat adalah: untuk diameter maksimum agregat $31,5 \mathrm{~mm}=249,67 \mathrm{~kg} / \mathrm{cm}^{2} ;$ diameter maksimum agregat $16 \mathrm{~mm}=274,91 \mathrm{~kg} / \mathrm{cm}^{2} ;$ dan diameter maksimum agregat $8 \mathrm{~mm}=326,74 \mathrm{~kg} / \mathrm{cm}^{2}$. Berdasarkan hasil pengujian ini, menunjukkan bahwa kuat tekan beton rata-rata diameter maksimum agregat $16 \mathrm{~mm}$ adalah $10,11 \%$ lebih kuat dari beton dengan diameter maksimum agregat $31,5 \mathrm{~mm}$; dan kuat tekan beton diameter maksimum agregat $8 \mathrm{~mm}, 30,87 \%$ lebih kuat dari beton dengan diameter maksimum agregat $31,5 \mathrm{~mm}$.
\end{abstract}

Keywords : agregat, diameter maksimum, benda uji, kuat tekan.

Abstract: Aggregate is a natural mineral grains that serve as filler in concrete mix, and the greatest material contained in the concrete. These material influence on the properties of concrete, so that the diameter size selection is essential in making the concrete. This study aims to determine the effect of variations of aggregate maximum diameter to the compressive strength of concrete. In this study used 15 specimens, were divided into 3 groups witch each of 5 specimens. Each group is distinguished aggregate maximum diameter: $31.5 \mathrm{~mm}, 16 \mathrm{~mm}$, and $8 \mathrm{~mm}$. Specimens used in this study is the specimen cylinder with a diameter of $15 \mathrm{~cm}$ and $30 \mathrm{~cm}$ high. Speciment tested done at age of concrete 28 days. The average compressive strength of concrete for each group of test based on variations of the aggregate maximum diameter is: for the aggregate maximum diameter of $31.5 \mathrm{~mm}=249.67 \mathrm{~kg}$ / $\mathrm{cm} 2$; the aggregate maximum diameter $16 \mathrm{~mm}=274.91 \mathrm{~kg} / \mathrm{cm} 2$; and the aggregate maximum diameter of $8 \mathrm{~mm}=326.74 \mathrm{~kg} / \mathrm{cm} 2$. Based on these test results, show that the average compressive strength of the concrete for the aggregate maximum diameter of $16 \mathrm{~mm}$ is $10.11 \%$ stronger than the concrete with the aggregate maximum diameter of $31.5 \mathrm{~mm}$; and the strength of concrete aggregate maximum diameter of $8 \mathrm{~mm}, 30.87 \%$ stronger than the concrete with aggregate maximum diameter of $31.5 \mathrm{~mm}$.

Keywords: aggregate, maximum diameter, specimen, compressive strength. 
Beton terdiri dari campuran bahanbahan agregat (pasir, kerikil), semen, dan air. Kekuatan beton dipengaruhi oleh sifat dari bahan-bahan tersebut oleh karena itu perbandingan jumlah dari bahan-bahan tersebut harus diperhatikan dengan seksama agar diperoleh mutu beton sesuai dengan yang diinginkan.

Agregat adalah batuan alam yang terdiri dari butiran-butiran dalam ukuran tertentu yang jumlahnya terbesar $(60 \%-70 \%)$ dalam campuran beton (Mulyono 2005) sehingga berpengaruh besar terhadap kekuatan tekan beton. Kekuatan tekan beton diduga sehingga pemilihan ukuran diameternya merupakan bagian yang penting dalam pembuatan beton. Karena itu perlu dipelajari karakteristik agregat yang akan menentukan sifat beton yang akan dihasilkan.

Tujuan dari penelitian ini adalah untuk mengetahui pengaruh variasi ukuran agregat maksimum terhadap kuat tekan beton. Dalam penelitian ini, campuran beton dibagi dalam 3 kelompok, masing-masing kelompok dibedakan ukuran diameter maksimum agregat yaitu: $31,5 \mathrm{~mm}, 16 \mathrm{~mm}$, dan $8 \mathrm{~mm}$. Jumlah benda uji masing-masing kelompok adalah 5 buah, sehingga total benda uji berjumlah 15 buah.

Penelitian ini menggunakan bahan semen adalah Semen Tipe I produksi PT. Semen Andalas Indonesia. Agregat yang digunakan (pasir dan kerikil) berasal dari sungai Krueng Aceh dan air diperoleh dari Perusahaan Daerah Air Minum Kota Banda Aceh.
Jenis benda uji yang digunakan untuk pengujian kuat tekan adalah jenis benda uji silinder standar dengan ukuran diameter 15 $\mathrm{cm}$ dan tinggi $30 \mathrm{~cm}$. Pengujian kuat tekan dilakukan pada saat umur beton mencapai 28 hari. Penelitian ini dimulai dengan memeriksa sifat-sifat fisis dari bahan agregat beton. Pemeriksaan ini bertujuan untuk mengetahui mutu material yang digunakan untuk campuran beton.

Perencanaan campuran material beton digunakan metode American Concrete Institute (ACI 211.1-91) dan penyaringan bahan agregat didasarkan pada peraturan (Anonim, 1971) yaitu untuk agregat diameter maksimum agregat $31,5 \mathrm{~mm}, 16 \mathrm{~mm}$, dan 8 mm. Faktor air semen (FAS) yang digunakan adalah 0,5 dan slump test rencana adalah 7,5 $\mathrm{cm}-10 \mathrm{~cm}$.

Hasil kuat tekan rata-rata yang diperoleh dari penelitian ini adalah $249,67 \mathrm{~kg} / \mathrm{cm}^{2}$ untuk diameter maksimum agregat $31,5 \mathrm{~mm}$; $274,91 \mathrm{~kg} / \mathrm{cm}^{2}$ untuk diameter maksimum agregat $16 \mathrm{~mm}$; dan $326,74 \mathrm{~kg} / \mathrm{cm}^{2}$ untuk diameter maksimum agregat $8 \mathrm{~mm}$. Hasil yang diperoleh dari penelitian ini menunjukkan bahwa semakin kecil diameter agregat maksimum, maka semakin besar nilai kuat tekan beton yang didapatkan. Dengan demikian, hasil dari penelitian ini dapat dipakai sebagai pedoman bagi praktisi yang kesulitan memperoleh ukuran agregat maksimum yang umumnya dipakai pada suatu daerah. 


\section{KAJIAN PUSTAKA}

Agregat halus dan kasar sebagai bahan susun kasar campuran merupakan komponen utama beton. Nilai kekuatan serta daya tahan (durability) beton merupakan fungsi dari banyak faktor, diantaranya adalah nilai banding campuran dan mutu bahan susun, metode pelaksanaan pengecoran, pelaksanaan finishing, temperatur dan kondisi perawatan pengerasannya.

\section{Faktor Air Semen (FAS)}

Faktor air semen (FAS) adalah perbandingan antara berat air dan berat semen.

FAS $=\frac{\text { berat air }}{\text { berat semen }}$

Mulyono (2005) menyatakan, air diperlukan pada pembuatan beton untuk memicu proses kimiawi semen, membasahi agregat, dan memberikan kemudahan dalam pekerjaan beton (workability). Untuk air yang terlalu sedikit menyebabkan proses hidrasi tidak tercapai seluruhnya sehingga akan mempengaruhi kekuatan beton, oleh karena itu perbandingan air dengan semen (faktor air semen) menjadi penting.

Murdock (1999) berpendapat bahwa untuk semua tujuan, beton yang mempunyai faktor air semen minimal dan cukup untuk memberikan workabilitas tertentu yang dibutuhkan untuk pemadatan yang sempurna tanpa pekerjaan pemadatan yang berlebihan, merupakan beton yang terbaik.

\section{Sifat-Sifat Fisis Agregat}

Agregat berfungsi sebagai bahan pengisi, tetapi peranannya dalam menentukan kekuatan beton lebih kecil daripada semen. Agregat dengan sifat kekerasan, kepadatan, dan keawetan tinggi mempunyai sifat kekekalan yang baik, sehingga akan menghasilkan beton yang berkualitas tinggi. Pemeriksaan sifat-sifat fisis agregat meliputi pemeriksaan berat jenis (specific gravity), penyerapan (absorbs), berat volume agregat (bulk density), analisa saringan (sieve analysis) agregat, modulus kehalusan (fineness modulus), gradasi agregat, kadar air agregat.

\section{Gradasi agregat}

Gradasi agregat adalah distribusi dari variasi ukuran butir agregat. Gradasi agregat berpengaruh pada besarnya rongga dalam campuran dan menentukan workabilitas (kemudahan dalam pekerjaan) serta stabilitas campuran. Gradasi agregat ditentukan dengan cara analisa saringan, dimana sampel agregat harus melalui satu set saringan. Ukuran saringan menyatakan ukuran bukaan jaringan kawat dan nomor saringan menyatakan banyaknya bukaan jaringan kawat per inchi pesegi dari saringan tersebut, daerah grafik gradasi agregat bisa dilihat pada gambar 1. 


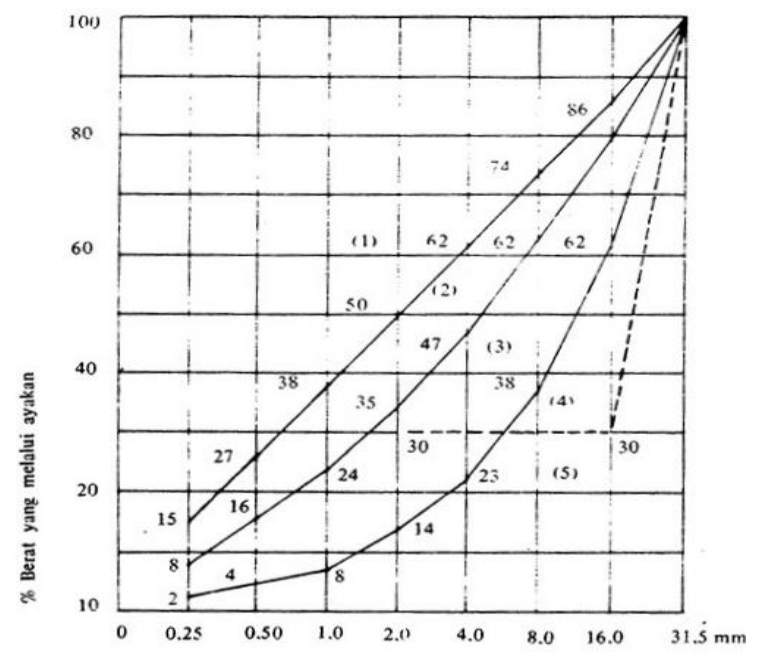

Gambar 1. Grafik daerah susunan butiran untuk agregat campuran dengan diameter maksimum 25,4 mm

Sumber: PBI 1971

Angka-angka dalam kurung pada

Gambar 1 mempunyai arti:

(1). Daerah tidak baik, diperlukan banyak semen dan air;

(2). Daerah baik, tetapi diperlukan banyak semen dan air dibandingkan dengan daerah (3);

(3). Daerah baik sekali;

(4). Daerah tidak baik untuk susunan butiran diskontinu;

(5). Daerah sangat tidak baik, terlalu sulit dikerjakan

\section{METODE PENELITIAN}

Penelitian ini dilakukan bertahap, yang dimulai dari pengadaan bahan dan peralatan, pemeriksaan sifat-sifat fisis agregat, pembuatan dan perawatan benda uji, pengujian benda uji dan analisa data.

\section{Pengadaan Peralatan dan Pengadaan}

\section{Material}

Peralatan yang digunakan untuk mendukung penelitian ini adalah:

1. Peralatan untuk pemeriksaan sifat-sifat fisis agregat:

a. Wadah (untuk menempatkan material yang akan diuji);

b. Oven;

c. Satu set saringan dengan berbagai ukuran.

2. Peralatan untuk pengadukan:

a. Cetakan benda uji silinder berukuran diameter $15 \mathrm{~cm}$ dan tinggi $30 \mathrm{~cm}$;

b. Mesin pengaduk beton (Mollen).

3. Peralatan untuk pengujian tekan beton digunakan mesin uji tekan

Material atau bahan yang dipakai dalam penelitian ini adalah:

1. Semen Portland Tipe 1;

2. Agregat kasar;

3. Agregat halus;

4. Air.

\section{Semen}

Semen yang digunakan pada penelitian ini adalah Semen Portland Tipe I yang diproduksi oleh PT. Semen Andalas Indonesia (SAI).

\section{Agregat kasar}

Agregat kasar yang digunakan yaitu kerikil yang berasal dari sungai Krueng Aceh. 


\section{Agregat halus}

Agregat halus yang digunakan adalah pasir kasar dan pasir halus, kedua-duanya berasal dari sungai Krueng Aceh.

Air

Air yang digunakan pada penelitian ini adalah air yang berasal dari Perusahaan Daerah Air Minum Kota Banda Aceh.

\section{Pemeriksaan Sifat-sifat Fisis Agregat}

Pemeriksaan sifat-sifat fisis material ini bertujuan untuk mengetahui mutu material masing-masing, apakah material tersebut memenuhi syarat untuk campuran beton. Pemeriksaan sifat-sifat fisis material di sini terdiri dari pengujian berat jenis agregat, berat volume dan analisa saringan.

\section{Berat jenis agregat}

Pengukuran berat jenis dilakukan berdasarkan metode British Standard. Agregat diambil secara acak masing-masing sebanyak $3 \mathrm{~kg}$. Agregat untuk kerikil masingmasing lolos saringan $31,5 \mathrm{~mm}, 16 \mathrm{~mm}$ (tetapi dipakai saringan $15 \mathrm{~mm}$ ), dan $8 \mathrm{~mm}$ dan untuk pasir halus lolos saringan 4,76 mm.

\section{Berat volume agregat}

Pemeriksaan ini dilakukan berdasarkan metode British Standard yang bertujuan untuk menentukan berat volume pada agregat. Agregat pada pemeriksaan ini diambil secara acak masing-masing sebanyak 2 kg.Agregat untuk kerikil masing-masing lolos saringan 31,5 mm, $16 \mathrm{~mm}$ (dipakai 15

Volume 3, No. 1, Januari 2017 $\mathrm{mm}$ ), dan $8 \mathrm{~mm}$ dan untuk pasir halus lolos saringan $4,76 \mathrm{~mm}$.

\section{Analisa saringan agregat}

Pemeriksaan analisa saringan butiran agregat dilakukan terhadap kerikil, pasir kasar, pasir halus. Agregat dalam pemeriksaan ini diambil secara acak. Agregat untuk kerikil yang digunakan masing-masing harus lolos saringan $31,5 \mathrm{~mm}, 16 \mathrm{~mm}$ dan 8 mm, untuk pasir kasar lolos saringan 9,52 mm. Agregat kemudian disaring sesuai dengan susunan saringan mulai dari diameter maksimum agregat yang dipakai sampai diameter minimumnya. Adapun ukuran saringan yang digunakan yaitu 31,5 mm, 19,1 mm, 9,52 mm, 4,76 mm, 2, $38 \mathrm{~mm}, 1,18 \mathrm{~mm}$, 0,59 mm, 0,29 mm, dan 0,15 mm. Untuk agregat maksimum 31,5 mm dipakai ukuran saringan mulai dari 31,5 mm sampai dengan $0,15 \mathrm{~mm}$ dan sisa. Untuk agregat maksimum $16 \mathrm{~mm}$ dipakai ukuran saringan mulai dari 16 mm sampai dengan $0,15 \mathrm{~mm}$ dan sisa. Untuk agregat $8 \mathrm{~mm}$ dipakai ukuran saringan mulai dari $8 \mathrm{~mm}$ sampai dengan $0,15 \mathrm{~mm}$ dan sisa. Begitupun untuk menganalisa saringan pasir kasar, dipakai ukuran saringan mulai dari 8 mm sampai dengan $0,15 \mathrm{~mm}$ dan sisa, sedangkan untuk pasir halus dipakai ukuran saringan $4,76 \mathrm{~mm}$ sampai dengan $0,15 \mathrm{~mm}$ dan sisa.

\section{Pengadukan Beton}

Pekerjaan ini dilakukan dengan
memasukkan seluruh material secara
berurutan, yaitu agregat kasar (kerikil),


agregat halus (pasir kasar dan pasir halus), semen, dan air yang telah ditimbang sesuai perencanaan ke dalam mesin pengaduk beton (mollen). Campuran material beton diaduk di dalam mesin pengaduk (mollen) selama \pm 3 menit.

\section{Pembuatan Benda Uji}

\section{a. Jumlah benda uji}

Jumlah benda uji yang dibuat pada penelitian ini adalah 15 buah yang terbagi dalam 3 kelompok. Masing-masing kelompok benda uji dibedakan ukuran diameter maksimum agregat yaitu: $31,5 \mathrm{~mm}$, $16 \mathrm{~mm}$ dan $8 \mathrm{~mm}$.

\section{b. Pembuatan benda uji}

Benda uji pada penelitian ini menggunakan benda uji silinder dengan diameter $15 \mathrm{~cm}$ dan tinggi $30 \mathrm{~cm}$. Beton segar yang telah diaduk dimasukkan ke dalam cetakan silinder secara bertahap, yaitu setiap 1/3 bagian silinder, sampai penuh. Cetakan benda uji silinder dibuka setelah benda uji berumur 24 jam.

\section{c. Perawatan benda uji}

Perawatan benda uji dilakukan dengan merendam benda uji kedalam bak air yang telah disediakan. Perawatan benda uji dilakukan sampai umur 28 hari.

\section{Pengujian Benda uji Beton}

Pengujian benda uji dilakukan pada umur 28 hari, dengan menggunakan mesin uji tekan. Pembebanan diberikan secara bertahap, sampai benda uji hancur. Berdasarkan hasil pengujian ini dapat diketahui perbandingan nilai kuat tekan dari

\section{HASIL DAN PEMBAHASAN}

\section{a. Hasil pemeriksaan}

Hasil yang diperoleh dari pemerikasaan sifat-sifat fisis agregat adalah sebagai berikut:

\section{Berat jenis agregat}

Hasil yang diperoleh dari pemeriksaan berat jenis agregat (kerikil, pasir kasar dan pasir halus) untuk tiap variasi diameter maksimum, diperlihatkan pada Tabel 3.1.

Berdasarkan Tabel 3.1 terlihat bahwa berat jenis agregat dengan diameter maksimum 31,5 mm, $16 \mathrm{~mm}$, dan $8 \mathrm{~mm}$ telah memenuhi syarat sebagai material yang baik untuk campuran beton.

\section{Berat volume agregat}

Hasil pemeriksaan berat volume agregat diperlihatkan pada Tabel 3.2. BerdasarkanTabel 3.2 terlihat bahwa hasil pemeriksaan berat volume agregat untuk masing-masing diameter maksimum agregat, yaitu: $31,5 \mathrm{~mm}, 16 \mathrm{~mm}$, dan $8 \mathrm{~mm}$ memenuhi syarat sebagai material untuk beton 
Tabel 3.1 Berat Jenis Agregat

\begin{tabular}{|c|c|c|c|c|}
\hline \multirow{2}{*}{ No. } & \multirow{2}{*}{ Jenis Agregat } & \multicolumn{2}{|c|}{ Berat Jenis } & \multirow{2}{*}{ Teori Troxell } \\
\hline & & $\mathbf{S G}_{(\text {(ssd) }}$ & $\mathbf{S G}_{(\mathrm{od})}$ & \\
\hline \multicolumn{5}{|c|}{ Agregat $31,5 \mathrm{~mm}$} \\
\hline 1. & Kerikil & 2,56 & 2,50 & $2,5-2,8$ \\
\hline 2. & Pasir Kasar & 2,07 & 2,03 & $2,0-2,6$ \\
\hline 3. & Pasir Halus & 2,50 & 2,44 & $2,0-2,6$ \\
\hline \multicolumn{5}{|c|}{ Agregat $16 \mathrm{~mm}$} \\
\hline 1. & Kerikil & 2,64 & 2,60 & $2,5-2,8$ \\
\hline 2. & Pasir Kasar & 2,36 & 2,34 & $2,0-2,6$ \\
\hline 3. & Pasir Halus & 2,46 & 2,43 & $2,0-2,6$ \\
\hline \multicolumn{5}{|c|}{ Agregat $8 \mathrm{~mm}$} \\
\hline 1. & Kerikil & 2,56 & 2,52 & $2,5-2,8$ \\
\hline 2. & Pasir Kasar & 2,18 & 2,14 & $2,0-2,6$ \\
\hline 3. & Pasir Halus & 2,31 & 2,26 & $2,0-2,6$ \\
\hline
\end{tabular}

Tabel 3.2 Berat Volume Agregat

\begin{tabular}{|c|c|c|c|}
\hline No & Jenis Agregat & Berat Volume (kg/l) & Teori Troxell \\
\hline \multicolumn{4}{|c|}{ Agregat $31,5 \mathrm{~mm}$} \\
\hline 1. & Kerikil & 1,750 & $>1560 \mathrm{~kg} /$ liter \\
\hline 2. & Pasir kasar & 1,615 & $>1,400 \mathrm{~kg} /$ liter \\
\hline 3. & Pasir halus & 1,501 & $>1,400 \mathrm{~kg} /$ liter \\
\hline \multicolumn{4}{|c|}{ Agregat $16 \mathrm{~mm}$} \\
\hline 1. & Kerikil & 1,742 & $>1560 \mathrm{~kg} /$ liter \\
\hline 2. & Pasir kasar & 1,613 & $>1,400 \mathrm{~kg} /$ liter \\
\hline 3. & Pasir halus & 1,486 & $>1,400 \mathrm{~kg} /$ liter \\
\hline \multicolumn{4}{|c|}{ Agregat $8 \mathrm{~mm}$} \\
\hline 1. & Kerikil & 1,622 & $>1560 \mathrm{~kg} /$ liter \\
\hline 2. & Pasir kasar & 1,607 & $>1,400 \mathrm{~kg} /$ liter \\
\hline 3. & Pasir halus & 1,476 & $>1,400 \mathrm{~kg} /$ liter \\
\hline
\end{tabular}




\section{Analisa saringan agregat}

Hasil yang diperoleh dari analisa saringan untuk masing-masing kelompok diameter maksimum agregat, yaitu: $31,5 \mathrm{~mm}$, $16 \mathrm{~mm}$, dan $8 \mathrm{~mm}$ telah memenuhi syarat sebagai material untuk beton, seperti terlihat pada Gambar 3.1, Gambar 3.2, dan Gambar 3.3.

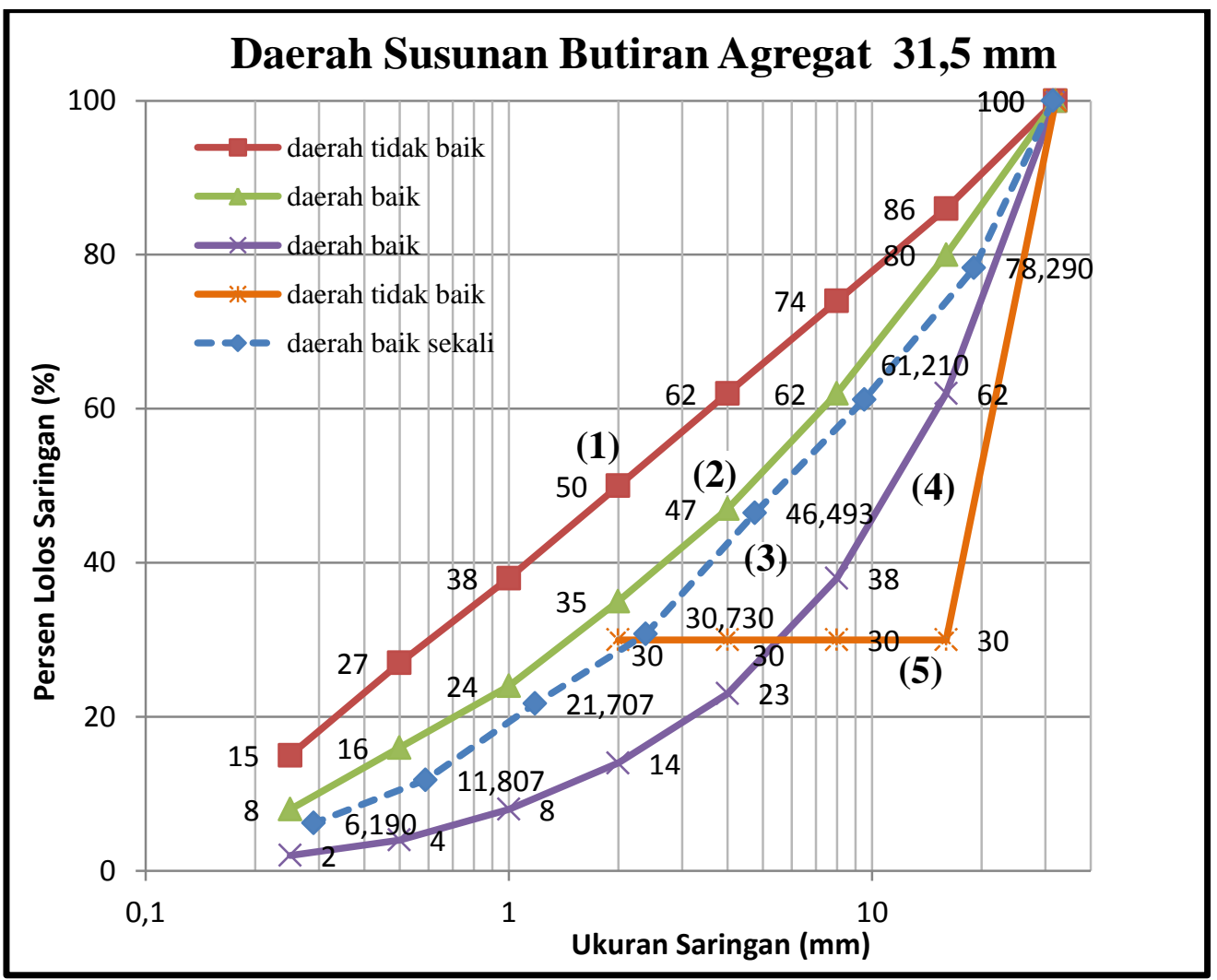

Gambar 3.1 : Daerah susunan butiran untuk agregat campuran dengan diameter maksimum 31,5 mm

\section{Hasil Pengujian Kuat Tekan Beton}

Hasil pengujian kuat tekan beton seperti terlihat pada Tabel 3.3.

\section{Perbandingan Hasil Pengujian Kuat Tekan}

Berdasarkan nilai hasil pengujian kuat tekan rata-rata dapat digambar grafik kuat tekan rata-rata dari masing-masing kelompok variasi diameter maksimum agregat, seperti terlihat pada Gambar 3.4. 


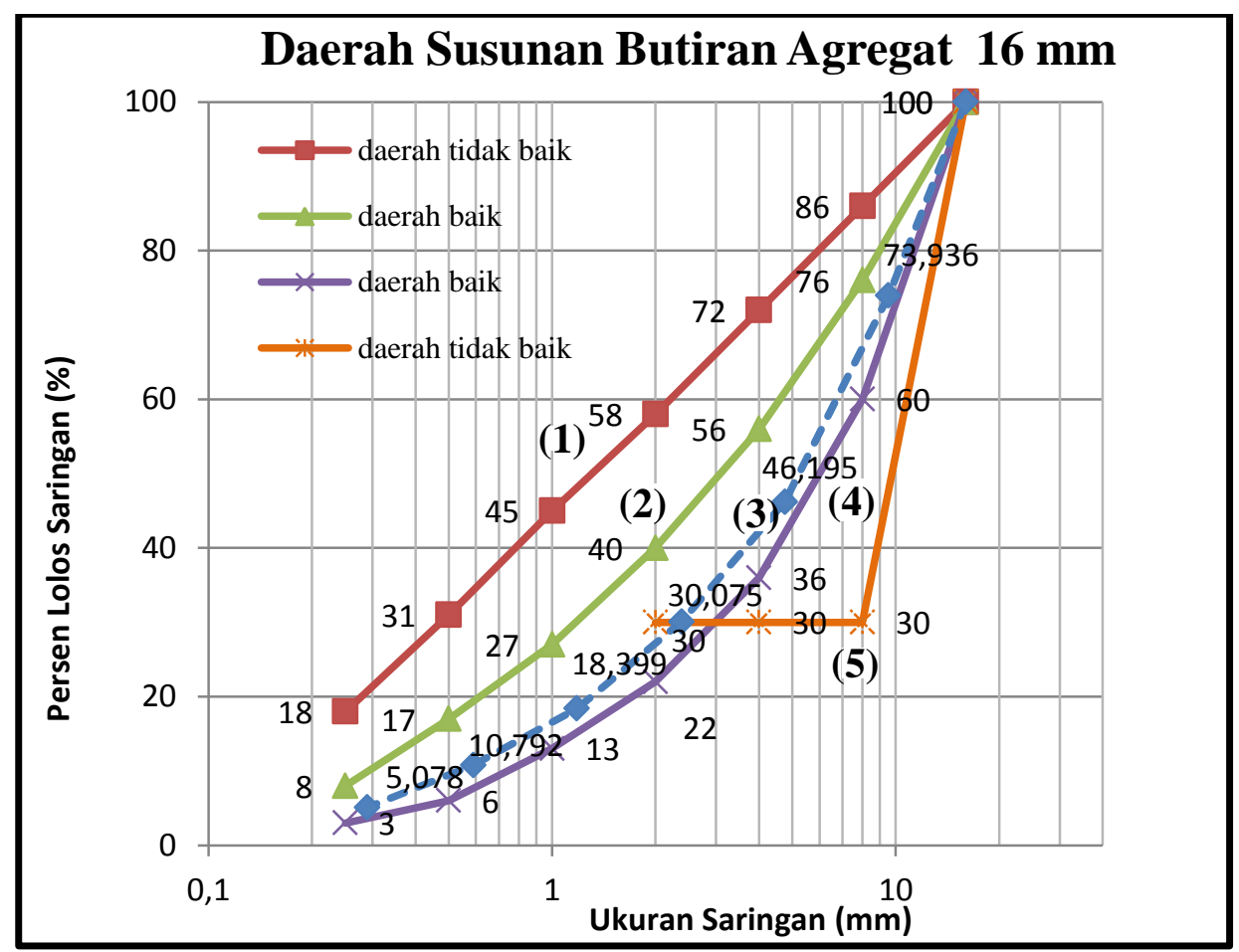

Gambar 3.2 : Daerah susunan butiran untuk agregat campuran dengan diameter maksimum $16 \mathrm{~mm}$

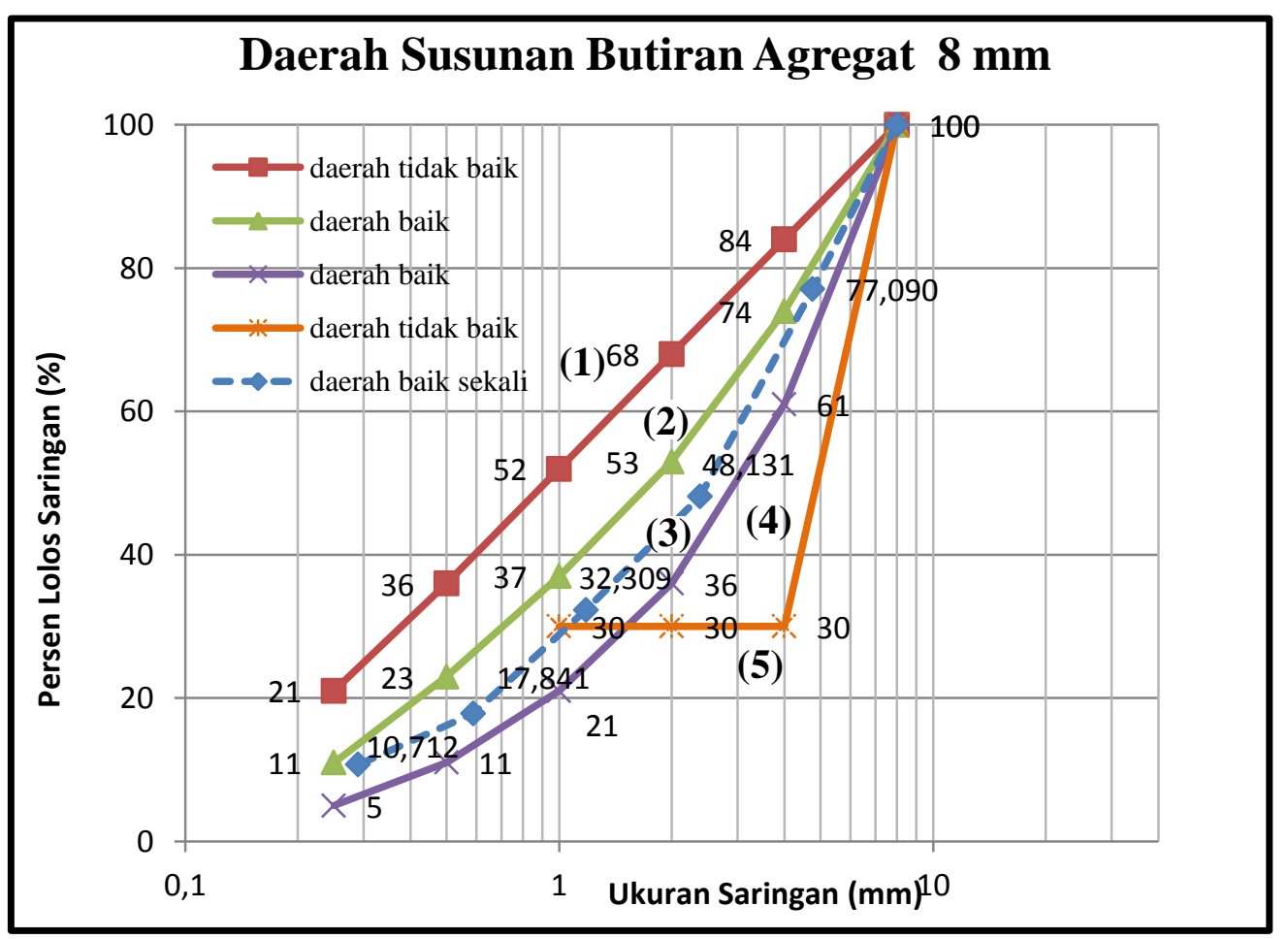

Gambar 3.3: Daerah susunan butiran untuk agregat campuran dengan diameter maksimum 8 mm 
Tabel 3.3 Hasil Pengujian Kuat Tekan Beton

\begin{tabular}{|c|c|c|c|c|c|}
\hline Jenis Beton & Umur & $\begin{array}{l}\text { Nama } \\
\text { Benda Uji }\end{array}$ & $\begin{array}{l}\text { Luas benda } \\
\text { Uji }\left(\mathrm{cm}^{2}\right)\end{array}$ & $\begin{array}{l}\text { Beban } \\
(\mathbf{K g})\end{array}$ & $\begin{array}{l}\text { Kuat Tekan } \\
\left(\mathbf{k g} / \mathrm{cm}^{2}\right)\end{array}$ \\
\hline \multirow{5}{*}{$\begin{array}{l}\text { Beton Agregat maks. } \\
31,5 \mathrm{~mm}\end{array}$} & \multirow{5}{*}{28 hari } & KA01 & 176,72 & 42300 & 239,37 \\
\hline & & KA02 & 176,72 & 46300 & 262,00 \\
\hline & & KA03 & 176,72 & 46100 & 260,87 \\
\hline & & KA04 & 176,72 & 45800 & 259,17 \\
\hline & & KA05 & 176,72 & 40100 & 226,92 \\
\hline & & \multicolumn{3}{|c|}{ Rata-rata Kuat Tekan Beton } & 249,67 \\
\hline Jenis Beton & Umur & $\begin{array}{l}\text { Nama } \\
\text { Benda Uji }\end{array}$ & $\begin{array}{l}\text { Luas benda Uji } \\
\left(\mathrm{cm}^{2}\right)\end{array}$ & $\begin{array}{l}\text { Beban } \\
(\mathrm{Kg})\end{array}$ & $\begin{array}{l}\text { Kuat Tekan } \\
\left(\mathrm{kg} / \mathrm{cm}^{2}\right)\end{array}$ \\
\hline \multirow{5}{*}{$\begin{array}{l}\text { Beton Agregat maks. } \\
16 \mathrm{~mm}\end{array}$} & \multirow{5}{*}{28 hari } & KB01 & 176,72 & 45400 & 256,91 \\
\hline & & KB02 & 176,72 & 51100 & 289,17 \\
\hline & & KB03 & 176,72 & 45000 & 254,65 \\
\hline & & KB04 & 176,72 & 52400 & 296,52 \\
\hline & & KB05 & 176,72 & 49000 & 277,28 \\
\hline & & \multicolumn{3}{|c|}{ Rata-rata Kuat Tekan Beton } & 274,91 \\
\hline \multirow{5}{*}{$\begin{array}{l}\text { Beton Agregat maks. } \\
8 \mathrm{~mm}\end{array}$} & \multirow{5}{*}{28 hari } & $\mathrm{KC} 01$ & 176,72 & 58700 & 332,17 \\
\hline & & $\mathrm{KC} 02$ & 176,72 & 62700 & 354,81 \\
\hline & & $\mathrm{KC03}$ & 176,72 & 61100 & 345,76 \\
\hline & & $\mathrm{KCO4}$ & 176,72 & 54700 & 309,54 \\
\hline & & $\mathrm{KC} 05$ & 176,72 & 51500 & 291,43 \\
\hline & & \multicolumn{3}{|c|}{ Rata-rata Kuat Tekan Beton } & 326,74 \\
\hline
\end{tabular}




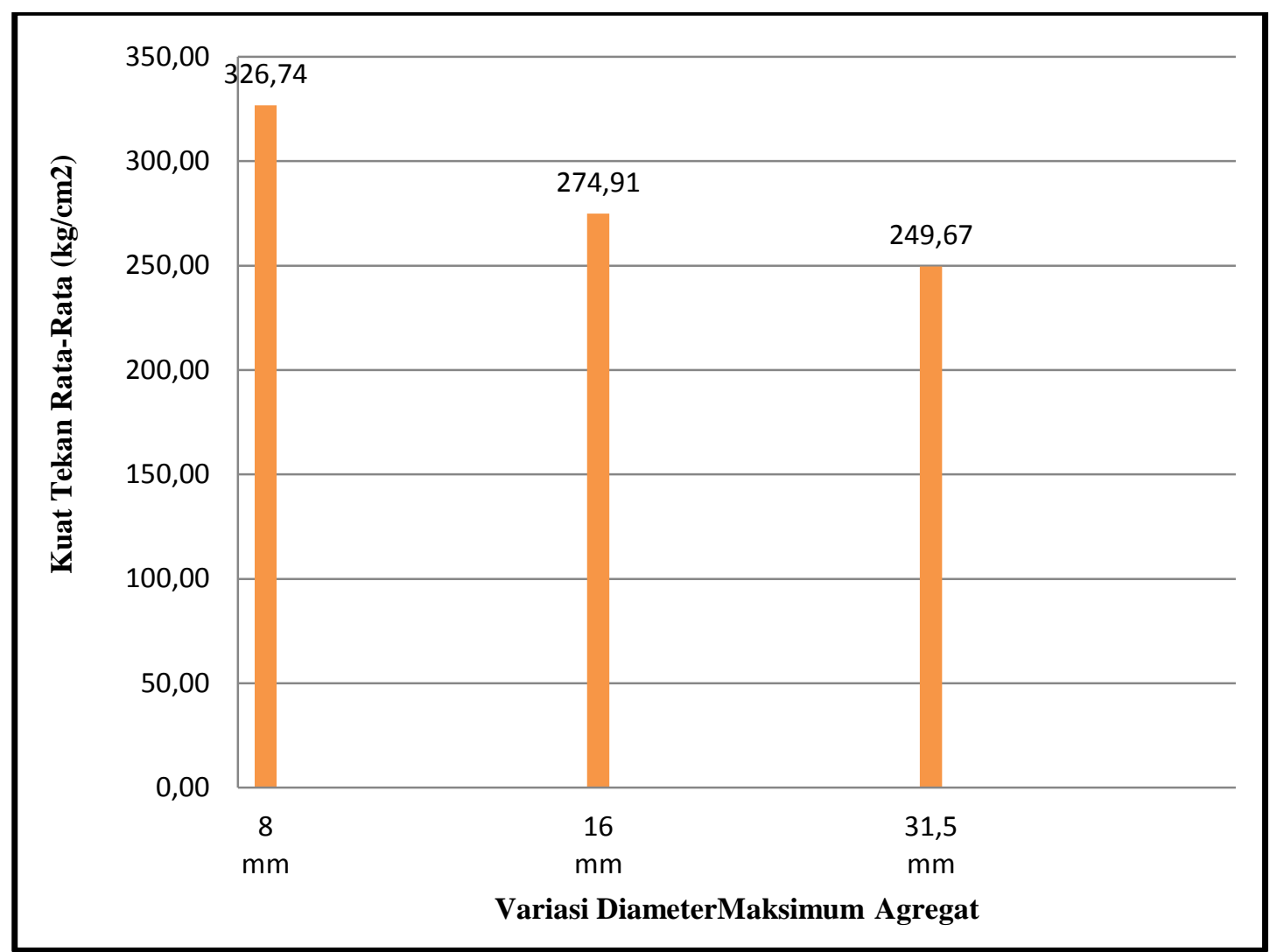

Gambar 3.4: Grafik Hasil Kuat Tekan Rata-rata Beton

Berdasarkan Gambar 3.4 dapat dilihat bahwa grafik hasil kuat tekan rata-rata yang diperoleh dari pengujian beton variasi diameter maksimum agregat ini adalah semakin kecil ukuran diameter maksimum agregat, maka semakin besar hasil kuat tekannya.

\section{Pembahasan}

Hasil pemeriksaan sifat-sifat fisis agregat menunjukkan bahwa agregat yang digunakan secara umum sudah memenuhi syarat sebagai material pembentuk beton.

Berdasarkan Gambar 3.4 dapat dilihat bahwa hasil pengujian ini menunjukkan adanya perubahan nilai kuat tekan pada beton, yaitu semakin kecil ukuran diameter maksimum agregat, semakin besar hasil kuat tekannya. Perbandingan persentase kenaikan kuat tekan beton variasi diameter maksimum agregat dapat dilihat pada Tabel 3.4. 
Tabel $3.4 \quad$ Perbandingan Persentase Kenaikan Kuat Tekan Beton Variasi Diameter Maksimum Agregat

\begin{tabular}{|l|l|l|l|l|}
\hline No & Perbandingan & $\begin{array}{l}\text { Agregat } \\
31,5 \mathrm{~mm} \\
\left(\mathrm{~kg} / \mathrm{cm}^{2}\right)\end{array}$ & $\begin{array}{l}\text { Agregat } \\
16 \mathrm{~mm} \\
\left(\mathrm{~kg} / \mathrm{cm}^{2}\right)\end{array}$ & $\begin{array}{l}\text { Agregat } \\
\mathrm{mm} \\
\left(\mathrm{kg} / \mathrm{cm}^{2}\right)\end{array}$ \\
\hline 1. & $\begin{array}{l}\text { Selisih kuat } \\
\text { tekan beton } \\
\text { agregat 31,5 } \\
\text { mm (kg/cm })\end{array}$ & 249,67 & 274,91 & 326,74 \\
\hline 2. & $\begin{array}{l}\text { Persentase } \\
\text { selisih kuat } \\
\text { tekan agregat } \\
31,5 \text { mm }(\%)\end{array}$ & 100 & 110,11 & 130,87 \\
\hline
\end{tabular}

Berdasarkan Tabel 3.4 di atas, dapat dilihat bahwa semakin kecil ukuran diameter maksimum agregat, maka semakin semakin besar kekuatan tekan beton.

\section{KESIMPULAN DAN SARAN}

Berdasarkan hasil penelitian terhadap beton dengan perbedaan ukuran maksimum agregat, maka dapat diambil kesimpulan dan saran sebagai berikut:

1. Agregat yang digunakan pada penelitian ini, sudah memenuhi syarat sebagai material pembentuk beton yang baik.

2. Diameter maksimum agregat berpengaruh terhadap kekuatan tekan beton, yaitu semakin kecil ukuran diameter maksimum agregat dalam campuran beton, akan semakin besar nilai kuat tekan beton.
3. Kuat tekan rata-rata yang diperoleh dari penelitian ini adalah 249,67 kg/cm ${ }^{2}$ untuk diameter maksimum agregat 31,5 $\mathrm{mm} ; \quad 274,91 \mathrm{~kg} / \mathrm{cm}^{2}$ untuk diameter maksimum agregat 16 $\mathrm{mm}$; dan $326,74 \mathrm{~kg} / \mathrm{cm}^{2}$ untuk diameter maksimum agregat $8 \mathrm{~mm}$.

4. Perbandingan kekuatan tekan terhadap beton diameter maksimum agregat $31,5 \mathrm{~mm}$ adalah: untuk beton diameter maksimum agregat $16 \mathrm{~mm}$ adalah $110,11 \%$, untuk diameter maksimum agregat $8 \mathrm{~mm}$ adalah $130,87 \%$

\section{Saran}

1. Untuk mendapat gambaran yang lebih detail, disarankan agar variasi diameter agregat maksimum dibuat lebih banyak.

2. Penelitian ini dapat dikembangkan lagi pada agregat lain, misalnya agregat dari bahan batu pecah atau agregat buatan. 


\section{DAFTAR PUSTAKA}

1. Amri, S. (2005). Teknologi Beton. Jakarta: Universitas Indonesia.

2. American Concrete Institute Committee (ACI) 211.1-77. (1977). Recommended Practice for Selecting Proportions for Normal, Heavyweight, and Mass Concrete. Detroit Michigan.

3. Anonim. (1991). Pelaksanaan Perawatan pada Beton. www.perawatan-beton.html, tanggal 08/07/2012, waktu 22:34:05.

4. Anonim. (1995). Annual Book of ASTM Standard 1995. Section 4. Volume 04.02, Concrete and Aggregates. International Standard-Worldwide.

5. Anonim. (2008). Modul III. B Melaksanakan Uji Kuat Tekan Beton. $\quad$ www.modul III.BBeton.html. tanggal 08/07/2012, waktu 20:35:02.

6. Departemen Pekerjaan Umum. (1971). Peraturan Beton Bertulang Indonesia NI-2. Jakarta.

7. Departemen Pekerjaan Umum. (1990). SNI-03-1974-1990: Metode Pengujian Kuat Tekan Beton. Bagian 3. Pusat Penelitian dan Pengembangan Pemukiman. Jakarta.

8. Departemen Pekerjaan Umum dan Bahan Penelitian dan Pengembangan PU. (2002). SNI 03-2835-2002: Syarat Teknis Bahan Bangunan. Pusat Penelitian dan Pengembangan Pemukiman. Jakarta.

9. Dipohosodo, I. (1994). Struktur Beton Bertulang Berdasarkan SK SNI T-15-1991-03. Jakarta: PT. Gramedia Pustaka Utama.

10. Mulyono, T. (2005). Teknologi Beton. Yogyakarta: Penerbit ANDI.

11. Murdock, L. J., dan Brooks, K. M. (1991). Bahan dan Praktek Beton. terjemahan Hindarko, S. Jakarta: Penerbit Erlangga.

12. Orchard, D.F. (1979). Concrete Technology Applied Science, Vol. 1. London: Applied Science.

13. Samekto, W., dan C. Rahmadiyanto. (1995). Teknologi Beton. Yogyakarta: Penerbit Kanisius.

14. Troxell, G.E., et al. (1968). Composition and Properties of Concrete, London: Mac Graw Hill Book Company. 